\title{
LITERATUR REVIEW : KUALITAS HIDUP PASIEN LEUKEMIA
}

\author{
Arslan Kamil Aries1, Budi Widyanto ${ }^{2}$, Sudirman ${ }^{3}$ \\ 1,2,3 Prodi Magister Terapan Keperawatan, Poltekkes Kemenkes Semarang
}

Corresponding author : arslankamil69@gmail.com

\begin{abstract}
Leukemia is a malignant disease that attacks the hematopoiesis system, causing uncontrolled blood cell proliferation. Quality of life is one indicator that can be used to see the welfare conditions of patients suffering from chronic diseases such as leukemia. This review literature aims to find out the factors that influence the quality of life of leukemia patients. Literature search through Google Scholar, EBSCO, Springer Link, Elsevier, Sage databases using keywords: factors, quality of life, leukemia. The journals taken have a range from 2018 to 2020, which are then filtered according to the inclusion criteria set by the author. The results of the review indicate that there are several factors that affect the quality of life in leukemia patients, namely the therapeutic treatment undertaken, the patient's environment, and the role of care giver. Proper management of leukemia patients will improve the quality of life of these patients, and vice versa.
\end{abstract}

Keywords : factors, quality of life, leukemia

\section{PENDAHULUAN}

Leukemia merupakan penyakit keganasan yang menyerang sistem hematopoiesis sehingga menyebabkan proliferasi sel darah yang tidak terkendali. Sel-sel progenitor berkembang pada sel yang normal, karena adanya peningkatan proliferasi sel dan penurunan apoptosis sel. Hal ini menyebabkan gangguan dari fungsi sumsum tulang sebagai pembentuk sel darah yang utama. Dimana penyakit ini identik menyerang pada anak-anak (Kulsum, Mediani, \& Bangun, 2017).

Di dunia kanker memiliki tingkat insiden sebesar 14,1 juta dimana 8,2 juta kasus mengalami kematian, sedangkan kanker hematologi mewakili sepersepuluh dari kasus keganasan yang terjadi di seluruh dunia (Ben Jannet et al., 2017). Tahun 2012, 10\% kematian pada anak di Indonesia disebabkan oleh kanker. Sedangkan data dari Riset Kesehatan Dasar pada tahun 2013 menunjukkan prevalensi kanker pada anak anak umur 014 tahun berjumlah 16.291 kasus. Dimana sepertiga diantaranya adalah leukemia, penyakit ini merupakan penyakit keganasan yang paling banyak menyerang anak-anak (Novrianda, Yetti, \& Agustini, 2016).

Kualitas hidup adalah suatu konseptual yang dapat diukur dan dilihat dari kemampuan atau cara pasien melakukan aktivitasnya selama dia sakit (Stevens et al., 2008). Dalam keperawatan, kualitas hidup merupakan konsep yang unik karena dapat mempengaruhi prognosis dari kondisi pasien. Terutama pada pasien yang menderita 
Jurnal Ilmu Keperawatan Medikal Bedah Vol. 4 (2), Bulan November Tahun 2020, Hal. 49-57 ISSN 2338-2058 (print), ISSN 2621-2986 (online)

penyakit kronis, kualitas hidup sangat diperhatikan karena merupakan salah satu indikator keberlangsungan hidup dari pasien tersebut (Novrianda et al., 2016).

Oleh karena itu, penulis tertarik untuk mereview literatur yang berhubungan dengan kualitas hidup (quality of life) pasien dengan leukemia. Tujuan dari literatur review ini untuk mengetahui faktor apa saja yang mempengaruhi kualitas hidup dari pasien yang mengalami leukemia. Diharapkan hasil literatue review ini bisa menambah wawasan bagi para tenaga kesehatan dalam penanganan dan pengelolaan pasien leukemia.

\section{METODE}

Literatur review bersumber dari beberapa jurnal nasional dan internasional yang berasal dari database Google Scholar, EBSCO, Springer Link, Elsevier, Sage dengan menggunakan kata kunci Google Scholar : factors, quality of life, leukemia; EBSCO : quality of life, leukemia; Springer Link : factors, leukemia; Elsevier dan Sage : factors, quality of life, leukemia. Jurnal yang digunakan disaring sesuai kriteria inklusi dan eksklusi yang ditetapkan oleh penulis. Kriteria inklusi dari literatur review ini adalah artikel jurnal yang berkaitan dengan kualitas hidup pasien leukemia, menggunakan bahasa Indonesia dan bahasa Inggris, tahun publikasi artikel jurnal pada tahun 2018 sampai dengan 2020. Kriteria eksklusi dari penulisan literature review ini adalah struktur artikel tidak lengkap (tidak mencantumkan metode penelitian, dan tidak melampirkan hasil penelitian), dan pembahasan tidak sesuai dengan tujuan pembuatan literatur review.

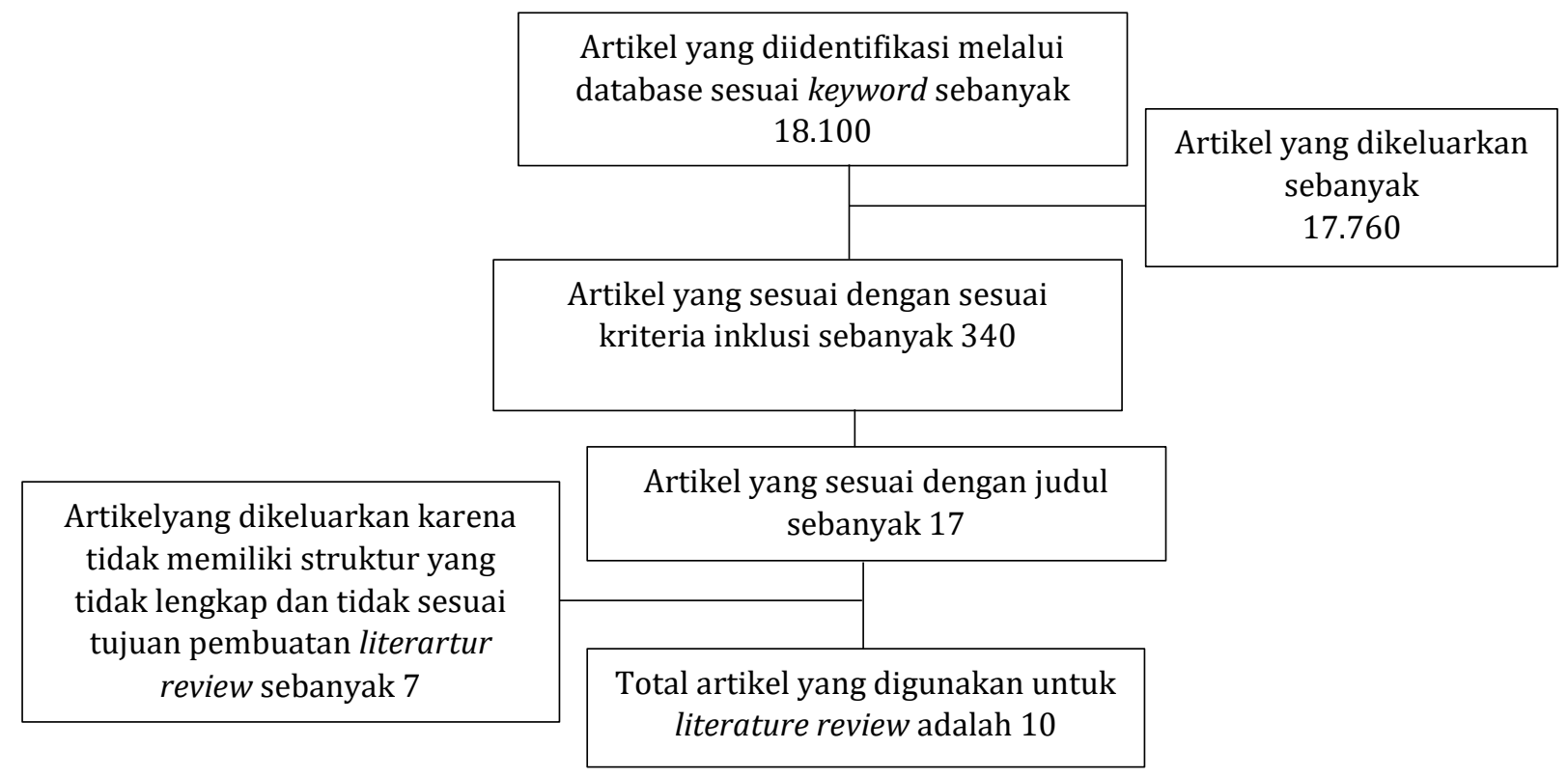

Bagan 1. Alur Screening Literatur 
Jurnal Ilmu Keperawatan Medikal Bedah Vol. 4 (2), Bulan November Tahun 2020, Hal. 49-57 ISSN 2338-2058 (print), ISSN 2621-2986 (online)

HASIL

Berdasarkan screening yang dilakukan, didapatkan hasil 10 artikel penelitian yang sesuai dengan tujuan penulisan yaitu tentang quality of life pada pasien leukemia. Berikut adalah hasil review 10 artikel penelitian tentang quality of life pada pasien leukemia.

Tabel 1

Hasi dari review hasil penelitian yang telah dilakukan

\begin{tabular}{|c|c|c|c|}
\hline Peneliti & Penelitian & $\begin{array}{c}\text { Jumlah } \\
\text { Responden }\end{array}$ & Hasil \\
\hline $\begin{array}{l}\text { Carol C. Choo et } \\
\text { al (2019) }\end{array}$ & $\begin{array}{l}\text { Health-Related } \\
\text { Quality of Life in } \\
\text { Pediatric Patients } \\
\text { with Leukemia in } \\
\text { Singapore: A Cross- } \\
\text { Sectional Pilot } \\
\text { Study }\end{array}$ & 60 & $\begin{array}{l}\text { Qualilty of life pasien } \\
\text { leukemia dipengaruhi oleh } \\
\text { usia pasien, durasi lama } \\
\text { pengobatan, dan etnisasi } \\
\text { dari lingkungan tempat } \\
\text { pasien tinggal. }\end{array}$ \\
\hline $\begin{array}{l}\text { Elena } \\
\text { Guadalupe et al } \\
(2018)\end{array}$ & $\begin{array}{lr}\text { Quality of Life and } \\
\text { Chronic } & \text { Health } \\
\text { Conditions } & \text { in } \\
\text { Childhood } & \text { Acute } \\
\text { Leukaemia } & \\
\text { Survivors } & \end{array}$ & 54 & $\begin{array}{l}\text { Quality of life pasien } \\
\text { leukemia dipengaruhi oleh } \\
\text { komorbiditas dan } \\
\text { pengobatan yang dijalani } \\
\text { oleh pasien tersebut }\end{array}$ \\
\hline \begin{tabular}{l}
\multicolumn{2}{l}{ Chunfeng } \\
Wang et al \\
$(2020)$
\end{tabular} & $\begin{array}{l}\text { Factors Associated } \\
\text { with Quality of Life } \\
\text { of Adult Patients } \\
\text { with } r \text { Acute } \\
\text { Leukemia and } \\
\text { Their ramily } \\
\text { Caregivers in China: } \\
\begin{array}{l}\text { A Cross- Sectional } \\
\text { study }\end{array} \\
\end{array}$ & 196 & 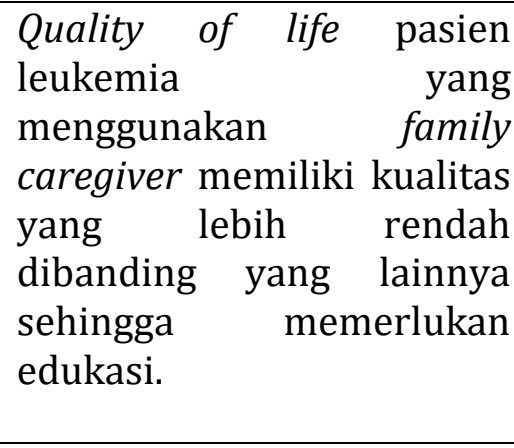 \\
\hline $\begin{array}{l}\text { Mauren K. Bult } \\
\text { et al (2019) }\end{array}$ & $\begin{array}{l}\text { Health-Related } \\
\text { Quality of Life of } \\
\text { Adolescents with } \\
\text { Cancer During the } \\
\text { First Year of } \\
\text { Treatment } \\
\end{array}$ & 73 & $\begin{array}{lr}\text { Quality of life } & \text { pasien } \\
\text { leukemia } & \text { dengan } \\
\text { pengobatan tahun pertama } \\
\text { dipengaruhi } \\
\text { pengobatan yang dijalani. }\end{array}$ \\
\hline $\begin{array}{l}\text { Fabio Efficace } \\
\text { et al (2019) }\end{array}$ & $\begin{array}{l}\text { Health-Related } \\
\text { Quality of Life of } \\
\text { Newly Diagnosed } \\
\text { Chronic Myeloid } \\
\text { Leukemia Patients } \\
\text { Treated with First- } \\
\text { Line Dasatinib } \\
\text { Versus Imatinib } \\
\text { Therapy }\end{array}$ & 188 & $\begin{array}{l}\text { Quality of life pasien } \\
\text { leukemia yang menerima } \\
\text { terapi dasanitib sebagi } \\
\text { pertolongan awal memiliki } \\
\text { kualitas yang lebih baik, } \\
\text { namun pada usia } 60 \text { tahun } \\
\text { keatas pemberian terapi } \\
\text { dasanitib perlu } \\
\text { dipertimbangkan untuk } \\
\text { kualitas hidup mereka }\end{array}$ \\
\hline
\end{tabular}



ISSN 2338-2058 (print), ISSN 2621-2986 (online)

\begin{tabular}{|c|c|c|c|}
\hline $\begin{array}{l}\text { Koung Jin Suh } \\
\text { et al (2019) }\end{array}$ & $\begin{array}{l}\text { Comparison of } \\
\text { Quality of Life and } \\
\text { Health Behaviors in } \\
\text { Survivors of Acute } \\
\text { Leukemia and The } \\
\text { General Population }\end{array}$ & 149 & $\begin{array}{l}\text { Quality of life pasien } \\
\text { leukemia dipengaruhi oleh } \\
\text { terapi pengobatan yang } \\
\text { dijalani, dimana mereka } \\
\text { yang menerima stem cell } \\
\text { therapy (SCT) memiliki } \\
\text { kualitas hidup yang buruk. }\end{array}$ \\
\hline $\begin{array}{l}\text { Areej El- } \\
\text { Jawahri et al } \\
(2019)\end{array}$ & $\begin{array}{l}\text { Quality of Life and } \\
\text { Mood of Older } \\
\text { Patients with Acute } \\
\text { Myeloid Leukemia } \\
\text { (AML) Receiving } \\
\text { Intensive and Non- } \\
\text { Intensive } \\
\text { Chemotherapy }\end{array}$ & 100 & $\begin{array}{l}\text { Quality of life pasien } \\
\text { leukemia dipengaruhi oleh } \\
\text { pengobatan yang diterima, } \\
\text { dimana pasien yang } \\
\text { memiliki pengalaman } \\
\text { dalam pengobatan memiliki } \\
\text { adaptasi yang lebih baik }\end{array}$ \\
\hline $\begin{array}{ll}\text { L. } & \text { Elise } \\
\text { Horvath et al } \\
(2019)\end{array}$ & $\begin{array}{l}\text { Real-World Impact } \\
\text { of Physician and } \\
\text { Patient } \\
\text { Discordance on } \\
\text { Health-Related } \\
\text { Quality of Life in US } \\
\text { Patients with Acute } \\
\text { Myeloid Leukemia }\end{array}$ & 539 & $\begin{array}{l}\text { Quality of life pasien } \\
\text { leukemia dipengaruhi oleh } \\
\text { tenaga kesehatan dalam } \\
\text { penentuan diagnosa dan } \\
\text { penanganan gejala yang } \\
\text { berulang. }\end{array}$ \\
\hline $\begin{array}{lll}\text { Charla } & & \text { M } \\
\text { Mamolo et } & \text { al } \\
(2019) & & \end{array}$ & $\begin{array}{l}\text { A Real-World, } \\
\text { Cross-Sectional, } \\
\text { Community Survey } \\
\text { of Symptoms and } \\
\text { Health-Related } \\
\text { Quality of Life of } \\
\text { Adults with Acute } \\
\text { Myeloid Leukemia }\end{array}$ & 68 & $\begin{array}{l}\text { Quality of life pasien } \\
\text { leukemia dipengaruhi oleh } \\
\text { terapi pengobatan yang } \\
\text { diterima, dimana kualitas } \\
\text { hidup lebih rendah dimilik } \\
\text { pasien yang mengalami } \\
\text { leukemia dibanding pasien } \\
\text { yang mengalami kanker } \\
\text { lainnya. }\end{array}$ \\
\hline $\begin{array}{l}\text { Christina } \\
\text { Ramsenthaler } \\
\text { et al (2019) }\end{array}$ & \begin{tabular}{lr}
\multicolumn{2}{l}{ Original Article } \\
Symptoms $\quad$ and \\
Anxiety Predict \\
Declining Health- \\
Related Quality of \\
Life in Multiple \\
Myeloma: \\
Prospective, Multi- \\
Centre \\
Longitudinal Study
\end{tabular} & 238 & $\begin{array}{lr}\text { Quality of life pasien dengan } \\
\text { myeloma dipengaruhi oleh } \\
\text { pengobatan yang diberikan, } \\
\text { sehingga } & \text { rejimen } \\
\text { pemberian } & \text { terapi } \\
\text { dipadukan } & \text { dengan } \\
\text { perawatan } & \text { paliatif dan } \\
\text { harus } & \text { dilakukan } \\
\text { pemantauan } & \text { secara } \\
\text { bertahap. } & \\
\end{array}$ \\
\hline
\end{tabular}


Jurnal Ilmu Keperawatan Medikal Bedah Vol. 4 (2), Bulan November Tahun 2020, Hal. 49-57 ISSN 2338-2058 (print), ISSN 2621-2986 (online)

\section{PEMBAHASAN}

Quality of life merupakan gambaran sebuah persepsi individu terhadap kehidupan mereka dalam konteks seperti budaya, kehidupan sosial baik secara individu maupun kelompok yang didalamnya mengandung unsur tentang tujuan hidup, harapan, standart dan fokus untuk apa mereka hidup. Didalam konsep tersebut terdapat beberapa dimensi yaitu: kesehatan fisik dan psikologis, hubungan sosial dan lingkungannya. Sedangkan kualitas hidup yang berhubungan dengan kesehatan adalah jarak antara objektif dengan subjektif dari individu, hal tersebut berasal dari rasa emosional, aktivitas sosial, hubungan kekerabatan, kepuasan, cita-cita, dan kepuasan untuk menjalani hidupnya (Corella Aznar et al., 2019).

Quality of life memiliki aspek-aspek yang dapat dinilai didalamnya, adapun aspek tersebut yaitu kesehatan fisik (aktivitas sehari-hari, konsumsi obat-obatan, alat batu medis, fase istirahat, dan kemampuan untuk bekerja), kesejahteraan psikologis (image tubuh atau gambaran citra diri yang meliputi harga diri, memori, konsentrasi, keyakinan pribadi, perasaan positif dan negatif), hubungan sosial (dukungan keluarga, teman, aktivitas seksual), hubungan dengan lingkungan (aksebilitas, kualitas, lingkungan rumah, peluang untuk memperoleh informasi) (Trask et al., 2013).

Pada pasien leukemia, quality of life merupakan salah satu indikator yang diobservasi untuk melihat kesejahteraan hidup pada pasien tersebut. Tentunya quality of life pasien leukemia dipengaruhi oleh beberapa faktor yang bisa membuat kondisi pasien tersebut bertambah buruk begitupun sebaliknya. Adapun faktor yang mempengaruhi kualitas hidup pasien leukemia yaitu :

\section{Terapi Pengobatan yang Dijalani}

Dari hasil review literatur yang dilakukan, mengatakan bahwa kualitas hidup (quality of life) pasien yang menderita leukemia dipengaruhi oleh terapi pengobatan yang dijalani. Pengobatan yang diterima oleh pasien leukemia meliputi kemoterapi, radioterapi, dan stem cell therapy (SCT) (Efficace et al., 2020). Dimana dari terapi tersebut menimbulkan efek samping secara fisik maupun psikologis, meskipun tujuan dari terapi tersebut untuk menunjang usia hidup pasien. Efek samping fisik yang diterima adalah nyeri yang dirasakan pada saat proses terapi (kemoterapi) dan kelelahan, sedangkan efek samping psikologis yang diterima adalah depresi, ansietas, dan gangguan fungsi peran (Ramsenthaler et al., 2019). Terlebih lagi durasi pengobatan yang panjang dan berkala juga sangat mepengaruhi kondisi fisik dan psikologis pasien tersebut. Pada beberapa literatur disebutkan bahwa untuk saat ini penatalaksaan rejimen terapi sudah dikombinasikan dengan paliatif care. Hal ini bertujuan untuk meningkatkan kualitas hidup pasien tersebut dengan edukasi dan bimbingan psikologis serta penataan harapan-harapan pasien (Mamolo et al., 2019). Sehingga dengan upaya tersebut diharapakan beban terapi yang dijalani dapat berkurang dan dapat meninggkatkan kondisi fisik dan psikologis pasien yang nanti berdampak pada peningkatan kualitas hidup dari pasien tersebut (Horvath Walsh et al., 2019). 
Jurnal Ilmu Keperawatan Medikal Bedah Vol. 4 (2), Bulan November Tahun 2020, Hal. 49-57 ISSN 2338-2058 (print), ISSN 2621-2986 (online)

\section{Lingkungan}

Lingkungan mempunyai dampak yang cukup signifikan terhadap kualitas hidup pasien. Dimana lingkungan tersebut merupakan salah satu sarana untuk beraktivitas pasien, sehingga sangat memperngaruhi kondisi fisik dan psikologis pasien (Wang et al., 2020). Perubahan peran sosial yang terjadi pada saat pasien sakit akan membawa dampak tersendiri bagi pasien tersebut, sehingga bisa mengakibatkan depresi dan ansietas. Tentunya dibutuhkan modifikasi lingkungan yang sesuai dengan pasien sehingga pasien dapat beradaptasi dengan kondisi fisiknya (Choo et al., 2019). Hal ini bertujuan untuk mengurangi resiko atau faktor-faktor yang dapat mempengaruhi kondisi dari pasien tersebut. Lingkungan yang supportif dapat meningkatkan kualitas hidup pasien, yang mana lingkungan tersebut dapat memfasilitasi aktivitas dan peran pasien sesuai kemampuan pasien saat sakit, sehingga dapat menjadikan motivasi tersendiri bagi pasien tersebut (ElJawahri et al., 2019).

\section{Peran Care Giver}

Care giver yang dimaksud meliputi tenaga medis, keluarga, teman ataupun pekerja sosial yang bertujuan untuk membantu pasien selama perawatan. Pada beberapa literatur menyebutkan bahwa care giver juga berpengaruh terhadap kualitas hidup dari pasien leukemia, peran care giver ini dapat mempengaruhi fisik dan psikologis dari pasien tersebut. Peran tenaga medis disini adalah mendiagnosa, memberikan terapi kepada pasien dan mengtasi gejala kekambuhan dari pasien tersebut (Bult et al., 2019). Pada beberapa jurnal disebutkan bahwa kegagalan pada saat mengatasi gejala kekambuhan mengakibatkan prognosis yang buruk terhadap pasien tersebut, sehingga harus dilakukan observasi secara berkala terhadap pasien tersebut. Peran dari keluarga adalah sebagai sistem support dan fasilitator bagi pasien, dimana fasilitator yang dimaksud adalah untuk membantu setiap aktivitas yang dilakukan oleh pasien. Salah satu literatur menyebutkan bahwa family care giver dapat memberikan prognosis yang buruk terhadap kondisi dari pasien (Suh et al., 2019). Hal tersebut didasari oleh kurangnya edukasi berupa informasi dan bimbingan kepada keluarga, yang mana pada beberapa keluarga mengatakan bahwa mereka tidak mengetahui tentang penyakit yang dialami oleh pasien, gejala kambuhan yang dialami, dan tatalaksana keluarga dengan anggota yang sakit. Sehingga upaya edukasi kepada keluarga harus ditingkatkan guna membantu pasien untuk memenuhi kebutuhannya selama sakit yang nantinya dapat meningkatkan kualitas hidup pasien, yang mana keluarga adalah orang yang menemani pasien setiap waktu (Wang et al., 2020). Pada salah satu literatur menyebutkan bahwa hampir semua pasien yang menderita leukemia mengalami depresi dan ansietas. Sehingga disini peran pekerja sosial adalah sebagai support psikologis bagi pasien tersebut, yang mana tidak setiap pekerja sosial bisa memberikan dukungan tersebut. Hanya pekerja sosial yang sudah diberikan pelatihan yang bisa memberikan support psikologis kepada pasien yang menderita penyakit prnyakit kronis termasuk kanker. 
Jurnal Ilmu Keperawatan Medikal Bedah Vol. 4 (2), Bulan November Tahun 2020, Hal. 49-57 ISSN 2338-2058 (print), ISSN 2621-2986 (online)

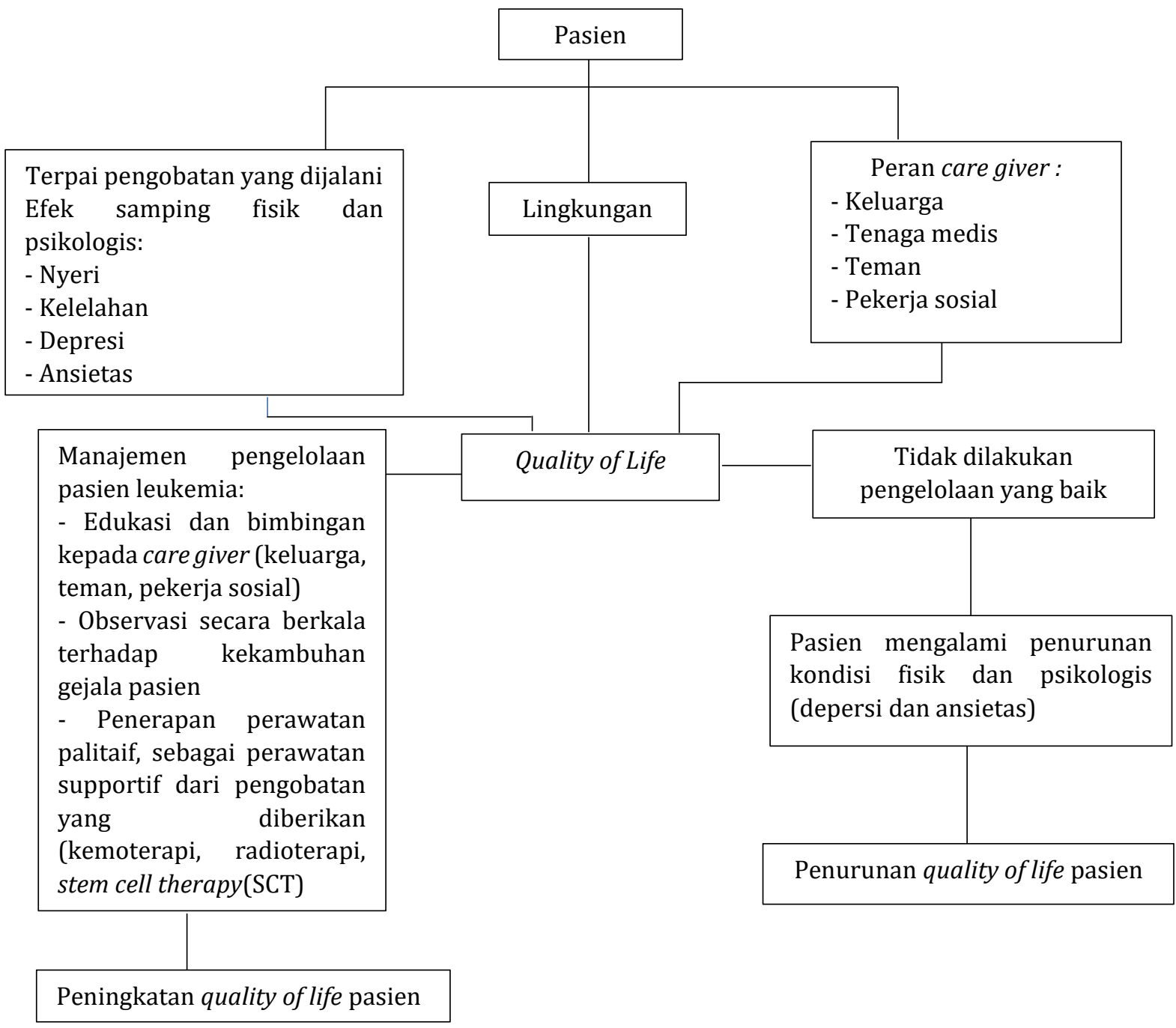

Bagan 2. Framework quality of life pasien leukemia

\section{KESIMPULAN}

Leukemia merupakan penyakit keganasan yang menyerang sistem hematopoiesis sehingga menyebabkan proliferasi sel darah yang tidak terkendali. Kualitas hidup (quality of life) pada pasien yang mengalami leukemia dapat menjadi indikator dari kondisi pasien tersebut. Berdasarkan hasil review literatur, disebutkan bahwa kualitas hidup dari penderita leukemia dipengaruhi oleh beberapa faktor yaitu terapi pengobatan yang diberikan, lingkungan, dan peran care giver. Pengeloaan yang tepat terhadap pasien leukemia dapat meningkatkan kualitas hidup pada pasien tersebut. 
Jurnal Ilmu Keperawatan Medikal Bedah Vol. 4 (2), Bulan November Tahun 2020, Hal. 49-57 ISSN 2338-2058 (print), ISSN 2621-2986 (online)

\section{DAFTAR PUSTAKA}

Ben Jannet, S., Hymery, N., Bourgou, S., Jdey, A., Lachaal, M., Magné, C., \& Ksouri, R. (2017). Antioxidant and Selective Anticancer Activities of Two Euphorbia Species in Human Acute Myeloid Leukemia. Biomedicine and Pharmacotherapy, 90, 375-385. https://doi.org/10.1016/j.biopha.2017.03.072

Bult, M. K., Van Bindsbergen, K. L. A., Schepers, S. A., De Ridder-Sluiter, H. G., Verhaak, C. M., Van Litsenburg, R. R. L., ... Grootenhuis, M. A. (2019). Health-Related Quality of Life of Adolescents With Cancer During The First Year of Treatment. Journal of Adolescent and Young Adult Oncology, 8(5), 616-622. https://doi.org/10.1089/jayao.2019.0017

Choo, C. C., Chew, P. K. H., Tan, P., Choo, J. Q., Choo, A. M. H., Ho, R. C., \& Quah, T. C. (2019). Health-Related Quality of Life in Pediatric Patients with Leukemia in Singapore: A Cross-Sectional Pilot Study. International Journal of Environmental Research and Public Health, 16(12), 1-10. https://doi.org/10.3390/ijerph16122069

Corella Aznar, E. G., Ayerza Casas, A., Carboné Bañeres, A., Calvo Escribano, M. Á. C., Labarta Aizpún, J. I., \& Samper Villagrasa, P. (2019). Quality of Life and Chronic Health Conditions in Childhood Acute Leukaemia Survivors. Medicina Clínica (English Edition), 152(5), 167-173. https://doi.org/10.1016/j.medcle.2019.01.004

Efficace, F., Stagno, F., Iurlo, A., Breccia, M., Cottone, F., Bonifacio, M., ... Rosti, G. (2020). Health-Related Quality of Life of Newly Diagnosed Chronic Myeloid Leukemia Patients Treated with First-Line Dasatinib Versus Imatinib Therapy. Leukemia, 34(2), 488-498. https://doi.org/10.1038/s41375-019-0563-0

El-Jawahri, A., Abel, G. A., Traeger, L., Waldman, L., Markovitz, N., VanDusen, H., ... Greer, J. A. (2019). Quality of Life and Mood of Older Patients with Acute Myeloid Leukemia (AML) Receiving Intensive and Non-Intensive Chemotherapy. Leukemia, 33(10), 2393-2402. https://doi.org/10.1038/s41375-019-0449-1

Horvath Walsh, L. E., Rider, A., Piercy, J., Pike, J., Wilson, S., Pandya, B. J., \& Medeiros, B. C. (2019). Real-World Impact of Physician and Patient Discordance on Health-Related Quality of Life in US Patients with Acute Myeloid Leukemia. Oncology and Therapy, 7(1), 67-81. https://doi.org/10.1007/s40487-019-0094-x

Kulsum, D. U., Mediani, H. S., \& Bangun, A. V. (2017). Pengaruh Swedish Massage Therapy terhadap Tingkat Kualitas Hidup Penderita Leukemia Usia Sekolah. Jurnal Keperawatan Padjadjaran, 5(2), 113-122. https://doi.org/10.24198/jkp.v5i2.449

Mamolo, C. M., Cappelleri, J. C., Hoang, C. J., Kim, R., Hadfield, A., Middleton, C., ... Walter, R. B. (2019). A Real-World, Cross-Sectional, Community Survey of Symptoms and HealthRelated Quality of Life of Adults with Acute Myeloid Leukemia. Future Oncology, 15(16), 1895-1909. https://doi.org/10.2217/fon-2018-0842

Novrianda, D., Yetti, K., \& Agustini, N. (2016). Faktor-Faktor Berhubungan dengan Kualitas Hidup Anak Leukemia Limfositik Akut yang Menjalani Kemoterapi. Jurnal Keperawatan Padjadjaran, v4(n1), 1-10. https://doi.org/10.24198/jkp.v4n1.1

Ramsenthaler, C., Gao, W., Siegert, R. J., Edmonds, P. M., Schey, S. A., \& Higginson, I. J. (2019). Symptoms and Anxiety Predict Declining Health-Related Quality of Life in Multiple Myeloma: A Prospective, Multi-Centre Longitudinal Study. Palliative Medicine, 33(5), 541-551. https://doi.org/10.1177/0269216319833588 
Jurnal Ilmu Keperawatan Medikal Bedah Vol. 4 (2), Bulan November Tahun 2020, Hal. 49-57 ISSN 2338-2058 (print), ISSN 2621-2986 (online)

Stevens, M., Frobisher, C., Hawkins, M., Jenney, M., Lancashire, E., Reulen, R., ... Winter, D. (2008). The British Childhood Cancer Survivor Study: Objectives, methods, population structure, response rates and initial descriptive information. Pediatric Blood \& Cancer, 50(5), 1018-1025. https://doi.org/10.1002/pbc

Suh, K. J., Shin, D. Y., Kim, I., Yoon, S. S., Lee, J. O., Bang, S. M., ... Koh, Y. (2019). Comparison of Quality of Life and Health Behaviors in Survivors of Acute Leukemia and The General Population. Annals of Hematology, 98(10), 2357-2366. https://doi.org/10.1007/s00277-019-03760-5

Trask, P. C., Cella, D., Powell, C., Reisman, A., Whiteley, J., \& Kelly, V. (2013). Health-related quality of life in chronic myeloid leukemia. Leukemia Research, 37(1), 9-13. https://doi.org/10.1016/j.leukres.2012.09.013

Wang, C., Yan, J., Chen, J., Wang, Y., Lin, Y. C., Hu, R., \& Wu, Y. (2020). Factors Associated with Quality of Life of Adult Patients with Acute Leukemia and Their Family Caregivers in China: A Cross-Sectional Study. Health and Quality of Life Outcomes, 18(1), 1-9. https://doi.org/10.1186/s12955-020-1269-8 